\title{
Research on the Construction of the Teaching Quality Management System of "School Enterprise Integration"
}

\author{
Xia Xianyu \\ ChongQing Real Estate College 401120
}

Keywords: "school-enterprise integration", higher vocational school, teaching, management Abstract

Abstract. Nowadays, China is in a critical period of developing economy, enhancing people's living standard, completing systems, developing science and education, strengthening the comprehensive national strength and participating in international cooperation and competition actively, so that the socialist industrialization and modernization can be realized soon. Therefore, both knowledge talents with a high level of knowledge and skilled talents with advanced technology are in great need. At present, many domestic higher vocational schools have adopted school running system of "school-enterprise integration". However, problems appear in practice due to the imperfect of China's higher vocational education. This paper focuses on the application of the school running system of "school-enterprise integration" in higher vocational education and the problem it exists, researches teaching quality monitoring system and teaching quality evaluation system to provide some reference for the development of China's higher vocational education.

As an important part of institutions of higher learning, China's higher vocational education is started in 1980s. After the rapid development for several decades, higher vocational education is gradually known by people and gradually got public recognition under the encouragement of national policies, though the process is burdensome. Recently, higher vocational education has a large enrolment. It has been a branch of education which is as important as colleges and universities. Compared with traditional higher vocational schools, the enrolment of higher vocational schools nowadays is very impressive. In addition to the large increase of students, the exploration and reform of higher vocational school are ongoing.

\section{School running model of "school-enterprise integration"}

"school-enterprise integration" is a product of the reform. As the name suggests, it refers to the integration of the two independent individuals---school and enterprise, make them a whole concept or have a close connection, and share each other's rights and obligations, the benefit and the risk. As a school running model, it aims to improve the competitiveness of their own to maximize their interests. "school-enterprise integration" is an organization which is on the basis of the guidance of the government, established between school, enterprise and society in order to cultivate high skilled personnel, do scientific research and develop technology and serve for all. "school-enterprise integration" is different from any precious school enterprise cooperation. The cooperation between school and enterprise is not just result cooperation. It requires companies fully participate in the teaching process. It is an advanced school enterprise cooperation form which aims to cultivate highly skilled personnel. In the process, projects for companies to participate are as follows: The curriculum and the development and implementation of measures to cultivate personnel in the early stage; the setting and implementing of majors, teacher training programs, and the selection of materials in the middle stage; the campus management, internship base, and the employment of students in the later stage and so on. With the support of local government, schools and enterprises establish a mutual benefit cooperation to make schools, enterprises and society be better by way of long-term and effective cooperation. Therefore, "school-enterprise integration" is a feasible school running concept and school running model in the field of higher vocational education. It is also an inevitable trend of the overall reform and development of higher vocational education in the future. 


\section{Problems exist in education management in "school-enterprise integration" model}

With the rapid development of national economy, the demand for high quality talent is growing. Real society is desperately short of highly skilled personnel have skills. Higher vocational institutions is shouldering with the important task of training technical personnel need by the community. Thus, the demand for higher vocational talents is growing in the society. Especially since China's accession to WTO, the Ministry of Education constantly issued a series of document on the reform of teaching quality of higher vocational education in order to cultivate more high skilled personnel to meet the needs of domestic and foreign enterprises. Driven by some demonstrative higher vocational schools, the running and reform of higher vocational school is booming in China. School running model of "school-enterprise integration" appears. However, because the education funding, teaching resource and faculty is lagging and cannot be synchronized with the rapid expansion of enrollment, some problems exist in the teaching management of "school-enterprise integration" model. The most serious problem is the phenomenon of "school is popular, enterprise is unvalued" and the phenomenon of teachers' focusing on knowledge and ignoring skills.

\subsection{The problem of "school is popular, enterprise is unvalued" is serious}

With the effort of the society, the exploration on "school-enterprise integration" model has made great achievements. Although "school-enterprise integration" model is accepted and supported by the public and is gradually mature, problems exist in the model gradually appear in the implementation process. The phenomenon of "school is popular, enterprise is unvalued" is the most serious one among the problems. For "school-enterprise integration" is a cooperation between school and enterprise which is promoted by the executive order of educational authorities. Schools and enterprises are both the perpetrators of "school-enterprise integration". Both sides did not consider the cooperation as the deep rooted idea or deeply understand the real connotation of "school-enterprise integration". They even did not recognize the importance of in-depth cooperation. The cooperation and the collaboration only stay at the surface level. There are quite a number of students in higher vocational schools. However, not many of them can intern in the enterprise or get a job opportunity. The reason of "school is popular, enterprise is unvalued" is that there is not enough enterprises participate in "school-enterprise integration". Although the government has tried to play a leading role, enterprises' enthusiasm of the participating is not very high. Hence, more enterprises should be attracted to participate in "school-enterprise integration" model and expand the scope of business cooperation to change the phenomenon.

\subsection{The phenomenon of focusing on knowledge and ignoring skills generally exist among teachers}

Since the implementation of university enrollment policy in China in 1998, a large number of graduates entered the society which added new vitality to teaching profession. Statistics in 2014 from the Ministry of Education is shown in figure 1: 


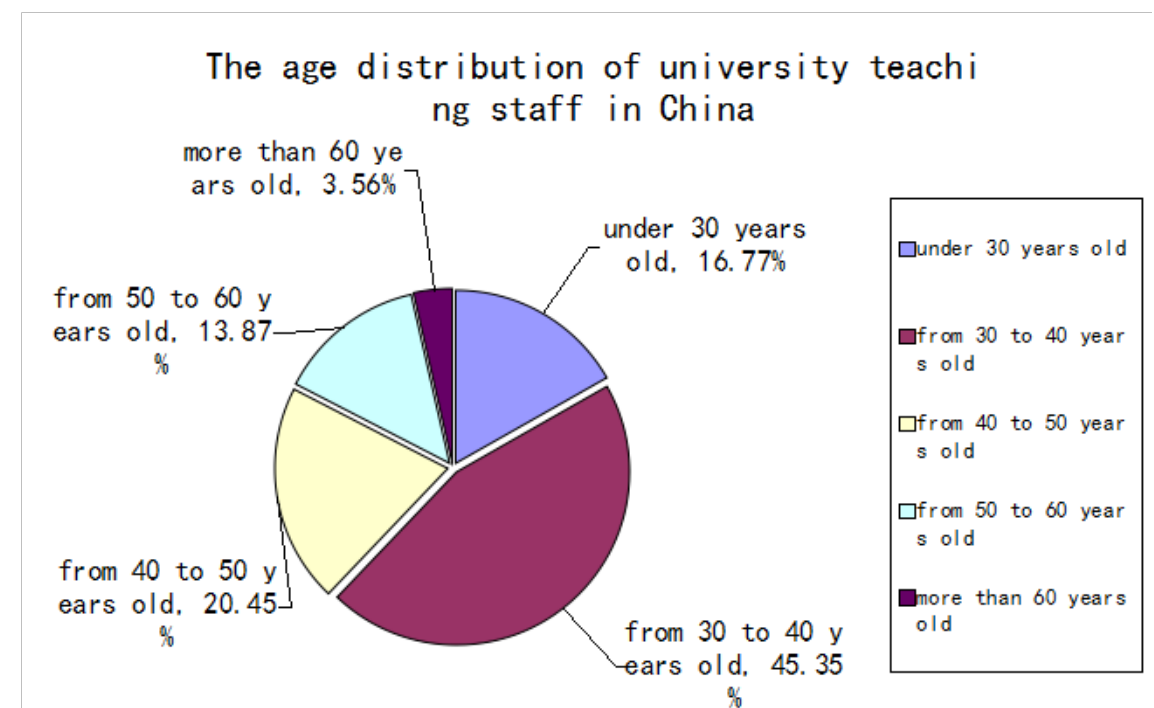

Figure 1: The age distribution of university teaching staff in China

As is shown in figure 1, up to the year 2014, among all of the in-service teachers in colleges and universities, $60 \%$ of them are under 40 years old. Teachers who are more than 50 years old accounted for less than $20 \%$. The average age of teachers in colleges and universities nationwide is 40 years old. Thus, although many students in higher vocational colleges are graduation of prestigious universities, their professional knowledge and attainment is high, the teaching experience is also very rich, they lack of practical experience, and the ability of practice. Therefore, more theoretical knowledge are taught in the teaching process, which makes higher vocational school teachers limited to book knowledge teaching and ignore the importance of practical skills. This result in the poor abilities of students and the low levels of practical skills. While some experienced teachers are on the contrary. The wrong teaching method will cause bad teaching effectiveness which may has a negative impact on students' overall development, skill master and the employment.

\section{The teaching quality monitoring system of "school-enterprise integration"}

Quality is the basis of enterprises. It decides the market shares, the economic benefit and the survival and development of the enterprise. For education, the quality is the lifeline of education, which is indespensible from the growth of children and the future of the family and nation. Therefore, for higher vocational education, even under the school system of "school-enterprise integration", the quality of teaching has been the focus of public attention. The detection of the quality of higher vocational schools are increasingly becoming an important symbol of the benefit evaluation of higher vocational schools. "Quality" has become an important symbol of the measure of a country's level of development. Under the background of globalization, teaching quality plays a decisive role in the development of school. The test of the teaching quality of higher vocational schools under the teaching mode of "school enterprise integration" can not be slack off.

The feature of vocational education is the key to the success of higher vocational schools. The establishment of a comprehensive set of teaching quality monitoring system is an important part to better achieve the target of "school-enterprise integration" model. The test of teaching quality can be divided into internal monitoring and external inspection. Internal monitoring means that teachers should pay attention to the implementation of the teaching objectives in the teaching process, and apply teaching quality to everyday teaching. External detection means that the education department or school administration checks or judges the teaching quality through unified examinations and other forms of examinations. Despite the form of internal and external monitoring is different, both of them aim to help teachers to dissolve teaching objectives in the teaching process, 
continuously improve the teaching methods and teaching quality through discovery, guidance and regulation.

The teaching quality monitoring system of "school enterprise integration" model is divided into three parts. The first part is speciality provision. The monitor of speciality provision is the basic link in the teaching quality monitoring system in higher vocational schools, and its purpose is to judge whether the speciality provision is consistent with the training objective of higher vocational schools.

The second part is the monitoring of teaching process. For higher vocational schools, it contains two parts: classroom and practice. Monitoring of classroom teaching is the most important part of teaching quality monitoring. Monitoring of classroom of "school enterprise integration" model needs to be done under the joint efforts of schools, enterprises and society. The concrete method is that the three parties respectively select persons to join in the classroom, monitor and evaluate all aspects of classroom teaching, then feedback to the teacher. The monitor of the process of teaching practice is mainly to monitor students' internship and training, provide more practice opportunities which are in line with their professional knowledge and improve their professional quality and skill level.

The third part is the monitoring of teaching resources. Teaching resources mainly refers to teacher resources. Only the teaching staff who is full of teaching and practice experience can help students improve their ability of practice. The "school enterprise integration" model can be better developed and implemented, and the characteristics of higher vocational schools can be better achieved.

The coordination and connection of each element of teaching quality monitoring system of higher vocational education is the foundation to ensure the smooth development and running of higher vocational schools. The setting of the monitoring system not only makes the training objective of the personnel become clear, but also improves the teaching staff. It strongly promotes the rapid and good development of higher vocational schools.

\section{Research of the teaching quality evaluation system of "school-enterprise integration"}

Higher vocational school is an important part of higher education institution in China. It provides services for the community and the construction of the first line, and cultivates high skilled talents for colleges and universities. Due to China's implementation of the enrollment expansion policy at the end of the last century once had a great effect on the teaching quality of many domestic higher vocational schools. Even in the tilt of national education policies and related documents, the quality of higher vocational education continues to be suspected and concerned by the public. It has become one of the issues to be solved urgently in the current higher education. A complete set of teaching quality evaluation system has great significance on the improvement of the quality of teaching. Therefore, it is necessary to establish a comprehensive and efficient teaching quality evaluation system.

Under the "school enterprise integration" model, the education quality evaluation system is mainly composed by the education component led to higher vocational colleges based enterprises to actively participate in wide-ranging vocational education. It also indicates that the government, businesses and schools start from different perspectives, and give full play of the teaching quality evaluation system of higher education which is gradually formed under the "tripartite linkage" model of education: regard school as the core, the executive branch of government as the lead, the community widely participate.

The content of evaluation mainly includes three aspects. The first aspect is the evaluation of students' learning effect and the quality of learning, because students are the direct audience of education, students' learning quality is related to the teaching quality of higher vocational schools. The higher vocational colleges of "School enterprise integration" model should aim to foster the students' professional skills and comprehensive technology, to exercise students' practical ability and the ability to operate, to inspire students' innovation ability, and to encourage students to actively obtain employment and entrepreneurship, on the basis of theoretical knowledge. It means 
that the evaluation of students' learning quality is based on theoretical knowledge and mainly about practical ability.

The second aspect is the evaluation of teaching quality. Teachers play an important role in improving the teaching quality of higher vocational schools. The evaluation of teaching quality mainly contains two parts. One is the evaluation of "double division" teacher quality, the other one is teachers' grasp of theory teaching and practice teaching. "Double division" refers to that teachers not only have the relevant expertise and qualifications, but also have the basic quality of teachers. The higher vocational teachers in the "school enterprise integration" model also need to have the work experience of the enterprise or the work experience of the social front line.

The third aspect is the evaluation of practical hardware condition in higher vocational schools, which includes teaching conditions such as campus environment, students' basic necessities of life conditions, school practice and training base, and the construction of the laboratory. Because the condition of practice teaching is a key factor to guarantee the promotion of the teaching quality of higher vocational schools, students can develop their basic skills and professional skills by practicing, based on learning the theory foundation knowledge. Therefore, the practical teaching condition determines the students' practical ability and the level of professional skills. According to the above three aspects of the evaluation design, specific to the indicators is shown in Table 1.

Table 1 The evaluation index of teaching quality

\begin{tabular}{|c|c|c|}
\hline first grade indexes & secondary index & index evaluation \\
\hline & learning quality & job completion rate \\
\hline \multirow[t]{3}{*}{ students learning situation } & & examination results \\
\hline & learning effect & number of innovations \\
\hline & teaching level & students understanding \\
\hline \multirow[t]{2}{*}{ teachers teaching quality } & overall quality & $\begin{array}{l}\text { educational background and } \\
\text { professional title evaluation value }\end{array}$ \\
\hline & practical experience & $\begin{array}{l}\text { practical life of enterprise } \\
\text { campus greening rate }\end{array}$ \\
\hline \multirow{4}{*}{$\begin{array}{l}\text { practice hardware } \\
\text { conditions }\end{array}$} & campus hardware & the number of laboratories \\
\hline & facilities & the scale of laboratories \\
\hline & & heating supply, water supply \\
\hline & training base & $\begin{array}{l}\text { the number of the training base } \\
\text { the scale of the training base }\end{array}$ \\
\hline
\end{tabular}

\section{Summary}

In summary, under the school running model of "school enterprise integration", teaching quality management system formed by the cooperation of the government's administrative departments of education, the management department of higher vocational college and enterprises has an important practical and positive significance on the development of higher vocational education in China. It not only promotes the reform and development of higher vocational schools, but also points out the direction for the active and in-depth cooperation between schools and enterprises. It also has a positive effect on the improvement of students learning quality in higher vocational schools, the improvement of the quality of teaching, the perfection of teaching management system, and the construction of the teaching staff.

\section{References}

[1] Agustus E Osseo-Asare,David Longbottom,Pieris Chourides.Man-agerial leadership for total quality improvement in UK higher education. TQM Magazine . 2007 
[2] Linying Zhang,Zhijun Han.Empirical Study on the Student Satisfaction Index in Higher Education. International Journal of Business and Management . 2008

[3] Geoffrey D. Doherty. On quality in education[J]. Quality Assurance in Education . 2008 (3)

[4] Sitalakshmi Venkatraman. A framework for implementing TQM in higher education programs[J]. Quality Assurance in Education . 2007 (1)

[5] Nina Becket,Dr Maureen Brookes.Quality Management Practice in Higher Education - What Quality Are We Actually Enhancing?. Journal of Hospitality, Leisure, Sports and Tourism Education . 2008 